\title{
Inclinations of greenhouse farmers in Turkey toward agricultural insurance
}

\author{
Ilkay Kutlar ${ }^{*}$ (D) Handan Akcaoz ${ }^{2}$ (D) \\ ${ }^{1}$ Department of Agricultural Economics, Faculty of Agriculture, Akdeniz University, 07059, Antalya,Turkey. E-mail: ikutlar@akdeniz.edu.tr. \\ ${ }^{*}$ Corresponding author. \\ ${ }^{2}$ Department of Agricultural Economics, Faculty of Agriculture, Akdeniz University, Antalya,Turkey.
}

\begin{abstract}
This study is explored the reasons why greenhouse farmers take out and do not take out agricultural insurance as well as the farmers' inclinations toward agricultural insurance and the factors that affect them so that agricultural insurance can be improved. In this context, three districts of Antalya where greenhouse farming is intensively carried out, namely Aksu, Serik and Kumluca, were selected as the research location, and face-to-face interviews were conducted with 200 farmers, 100 of which had agricultural insurance and 100 of which did not. The farms were divided into two groups, namely, those with and without insurance, according to the data obtained. The potential statistical relationship between some selected features of the farms under study and the farmers with and without insurance was identified by chi-square test. Furthermore, the inclinations, views and opinions of farmers with and without agricultural insurance concerning agricultural insurance were evaluated using a Likert scale. Among the reasons why farmers take out agricultural insurance are insuring their crop, avoiding any potential loss, securing their income and presence of disaster risk. The main reasons why farmers do not take out agricultural insurance is the registration and share problems of their lands.
\end{abstract}

Key words: greenhouse farming, agricultural insurance, farmer inclination, Antalya, Turkey.

Inclinações de agricultores de estufas em Turquia rumo ao seguro agrícola

RESUMO: O objetivo deste estudo é explorar as razões pelas quais os agricultores de estufas contratam e não realizam seguro agrícola, bem como as inclinações dos agricultores em relação ao seguro agrícola e os fatores que os afetam para que o seguro agrícola possa ser melhorado. Nesse contexto, três distritos de Antália, onde a agricultura de efeito estufa é intensamente realizada, foram selecionados como local de pesquisa, Aksu, Serik e Kumluca. Foram realizadas entrevistas presenciais com 200 agricultores, dos quais 100 tinham seguro agrícola e os outros 100 não. As fazendas foram divididas em dois grupos, com e sem seguro, de acordo com os dados obtidos. A relação estatística potencial entre algumas características selecionadas das fazendas em estudo e os agricultores com e sem seguro foi identificada pelo teste do qui-quadrado. Além disso, as inclinações, e opiniões dos agricultores com e sem seguro agrícola, em relação ao seguro agrícola, foram avaliadas usando uma escala Likert. Entre as razões pelas quais os agricultores fazem um seguro agrícola, estão assegurando sua colheita, sua renda, presença de risco de desastre e evintando possíveis perdas. A principal entre as razões pelas quais os agricultores não fazem seguro agrícola é o registro e o compartilhamento de problemas de suas terras.

Palavras-chave: cultivo de estufa, seguro agrícola, inclinação de fazendeiros, Antalya, Turquia.

\section{INTRODUCTION}

Agricultural activity is a risky business. In addition to risks related to price and yield, which affect their annual income, farmers also face natural disaster risks many times during a production period. Vegetable and animal production may suffer losses due to fire or weather events such as hail, frost and whirlwind. Farmers and their families may be affected by, accidents, diseases or death. Agricultural activity depends on many uncontrollable climatic conditions that affect the lives of farmers. Climate-related risks are significant for farmers in developing countries, particularly those that use traditional methods. Risks can be mitigated by various methods of farm management such as differentiation of agricultural activities or transferred to other sectors of the economy by methods such as agricultural insurance.

Risk management is crucial for the financing and investment decisions of farmers in developing countries. Agricultural insurance is one of the risk management tools to protect farmers against risks. Although agricultural insurance is frequently mentioned as one of the risk management tools,

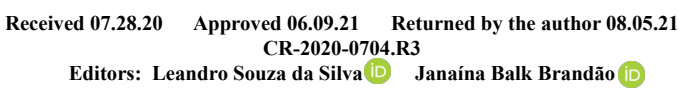


it plays a limited role in risk management related to agriculture. Agricultural insurance is an economic and social measure that helps reduce volatility in farmers' income. It is not an investment instrument, but a risk management tool that is used to insure cash income. The main purposes of agricultural insurance are to transfer risks so that income volatility is reduced, to decrease government's financial responsibility, to secure economic development in agricultural areas and farmers' right to borrow loans, to reduce social impacts of natural disasters on those engaged in agriculture and to enable farmers to use their savings more effectively.

In addition to its vital importance for the world population, the agricultural sector is a unique and exceptionally sensitive field of activity, highly affected by economic, social, political, technological and personal risks. From this point of view, the effective functioning of agriculture in the nutrition of humanity is directly associated with the management of risks threatening agricultural production. Hence, developed countries share and transfer risks through various protection policies, "Risk Management Programs" and "Agricultural Insurance Practices", which have an important place in these programs. In Turkey, "Agricultural Insurance Law" was enacted in 2005 so that farmers can insure their income against the risks threatening the agricultural sector. An Insurance Pool was established for the purpose of achieving a standard in the insurance contracts to be entered into regarding the risks covered by the law, creating an appropriate environment for the transfer of the risks under optimum conditions, ensuring payment of compensation for the damages from a single centre, and developing and expanding the use of the agricultural insurances. Any action and procedure regarding this pool is carried out by Agricultural Insurance Pool Management Inc. (TARSIM), the shares of which are equally owned by the insurance companies that participate in the pool. Insurance companies issue insurance policies in their own name, but mandatorily transfer $100 \%$ of the risks and premiums to the pool. The government provides support to the farmers' insurance premium, exclusively to the insurance contracts entered into under the law. The use of the pool ensures that farmer income is insured against catastrophic risks that an insurance company alone cannot undertake, such as drought and frost. The capacity and scope of reinsurance are enhanced by promoting participation in reassurance, being knowledge, personnel and financial resources of insurance companies are used jointly and more effectively. Government's premium and excess of loss support is used more effectively, that unfair competition which is prevented and a higher number of farmers are insured (TARSIM, 2019).

There are both national and international studies that explore the attitude, behaviour and inclinations of farmers toward agricultural insurance. Some studies focusing on the same subject as the present study are those conducted by HAYRAN et al., 2020; KIZILOGLU, 2017; YILMAZ et al., 2017; AYDIN et al., 2016; KARAMURSEL et al., 2014; SAYIN et al., 2014; TASCI et al., 2014; YILMAZ, 2014; ASLAN et al., 2012; ERTAN \& GOK, 2012; PEZIKOGLU et al., 2012; TAN et al., 2011, TUMER, 2011; YAVUZ, 2010; AKCAOZ et al., 2010; AKCAOZ et al., 2009; AKTER et al., 2008; CABAS et al., 2008; ENJOLRAS \& SENTIS, 2008 and FIELDS \& GILLESPIS, 2008).

Horticulture sector is very important in Turkish economy. Turkey has a suitable climate for growing many fruits and vegetables. Owing to differing climate and soil conditions over a large area Turkey has a wide range of horticulture products variety (YILMAZ et al., 2017). In Turkey, greenhouse cultivation started tentatively at research institutes in 1940s. Commercial greenhouses were constructed in Antalya and Izmir in 1970 (KUTLAR, 2019). According to the data by the Turkish Statistical Institute, Turkey's total population is 83.6 million, $7 \%$ of which live in rural areas. $16.7 \%$ of the employed population at and above 15 years of age work in the agricultural sector. Turkey has a total agricultural area of 23.4 million hectares. The number of agricultural land sections per enterprise is 5.9 and the average size of agricultural land sections is 1.29 hectares (TURKSTAT, 2019). Antalya is one of the prominent touristic and agricultural hubs in Turkey. It is the fifth largest province in terms of population. Its value of agricultural production is 9.5 billion TRY. It accounts for $6.8 \%$ of the vegetable production of Turkey in terms of value. The province is home to approximately 156 thousand growers (ANONYMOUS, 2019a). Aksu, serik and Kumluca districts, where greenhouse cultivation is intensively carried out, were chosen as the research locations. In a study conducted on the greenhouse vegetable growers in Aksu, Antalya, their average age, family size, greenhouse experience and average greenhouse size were 48.5 years, 3.6 person, 23.7 years and 0.41 hectares (KUTLAR, 2019). Similar results were reported in the other studies focusing on the same subject (OZKAN et al., 2001; SAYIN et al., 2014).

This study explored the reasons why greenhouse farmers in Antalya take out and do not take out agricultural insurance as well as the farmers' 
inclinations toward agricultural insurance and the factors that affect them so that agricultural insurance can be improved. In this context:

$\checkmark \quad$ Socioeconomic characteristics (educational attainment, age group, income, etc.) of the farmers were identified;

$\checkmark \quad$ Attitude and behaviour of the greenhouse farmers toward agricultural insurance were identified; $\checkmark \quad$ Factors that affect this attitude and behaviour of farmers were explored;

$\checkmark \quad$ Farmers' views and opinions about agricultural insurance were evaluated.

\section{MATERIALS AND METHODS}

Antalya is one of the prominent touristic and agricultural hubs in Turkey. According to 2019 data, its population is 2.4 million and area is $20.177 \mathrm{~km}^{2} .17 .9 \%$ of its total area is agricultural lands, $9.8 \%$ meadow and pasture, and $72.3 \%$ forest and non-agricultural lands. The value of its annual agricultural output is 9.5 billion TRY. It accounts for $6.8 \%$ of the vegetable production of Turkey in terms of value. Thanks to its fertile soil and favourable climatic conditions, field crops and greenhouse cultivation are the primary means of livelihood of farmers. Forty thousand farmers are registered in the province according to the Farmer Registration System (FRS) (ANONYMOUS, 2019a). In Turkey, the total area of greenhouses has reached 79 thousand hectares, compared to 8.5 thousand hectares in 1988. The amount of vegetable production has increased from 2.6 million tons to 7.8 million tons in the same period. Antalya accounts for $1.5 \%$ of the total agricultural area, $40.6 \%$ of the greenhouse area and $48.9 \%$ of the greenhouse vegetable production in Turkey (TURKSTAT, 2019). Greenhouse farming is carried out in $7.9 \%$ of the total agricultural area of the province. Aksu, Serik and Kumluca account for $39.3 \%$ of the total greenhouse area (Table 1). In the province, 3.8 million tons of vegetables are grown in greenhouses and 883 thousand tons of vegetables in open fields annually. In terms of amount of vegetable production, Aksu (534 thousand tons), Serik (804 thousand tons) and Kumluca (688 thousand tons) are the top three districts (ANONYMOUS, 2019a). Hence, Aksu, Serik and Kumluca were chosen as the research locations.

The main material of the research is the data obtained from questionnaires distributed to greenhouse farmers in Antalya who have agricultural insurance and who do not. Attempts were made to reach statistical data and various reports on the subject as secondary data. Similar studies conducted on the subject in Turkey and other parts of the world were also drawn on.

According to the records of Antalya Provincial Directorate of Agriculture and Forestry, 61.2 million TRY was paid in damages to 3.743 farmers in the production period 2018-2019 due to disasters such as hail, storm, whirlwind, snow and hail weight, and flood (ANONYMOUS 2019b). The population of the study consists of a total of 2.789 farmers who have agricultural insurance and were previously affected by natural disasters in Aksu (625 farmers), Serik (1.651 farmers) and Kumluca (513 farmers) (Table 1). Neyman formula was used to calculate the sample size by stratified sampling method (YAMANE, 2001). In calculating the sample size, the margin of error was assumed to be $5 \%$ of the population mean and the confidence interval was $95 \%$. Accordingly, the number of businesses to be interviewed was determined to be 100 .

In some cases, it may be sufficient to interview some of the farmers in a village or region. In such cases, the farmers to be interviewed are determined on purpose (CICEK \& ERKAN, 1996). For this reason, purposeful sampling method was employed to select the farmers without agricultural insurance. Since comparisons would be made between farmers with and without agricultural insurance, the same number of farmers without agricultural insurance living in the same village as and possessing similar personal and business characteristics to the farmers with agricultural insurance were selected on purpose. Accordingly, face-to-face interviews were conducted with a total of 200 farmers, 100 of which had agricultural insurance and 100 of which did not. This study was conducted for a period of two months starting from May to June 2019.

The data derived from the questionnaire survey were analysed on SPSS 20.0 for Windows. Mean values, frequencies, percentage distributions and cross tables were used in the analysis of the data. The businesses were divided into two groups, namely, those with and without agricultural insurance. The potential statistical relationship between some selected features of the businesses under study and the farmers with and without insurance was identified by chi-square test. The chi-square test is a nonparametric statistical test and requires data to show frequencies. Chi-square test is applied to check whether there is a relationship between expected frequencies and observed frequencies. In order for the chi-square test to be applied, the expected value should not be zero in each cell and the number of cells with an expected 
Table 1 - General details of the research locations.

\begin{tabular}{|c|c|c|c|c|c|}
\hline \multirow[t]{2}{*}{ Districts } & \multirow[t]{2}{*}{$\begin{array}{l}\text { Agricultural area } \\
\text { (hectare) }\end{array}$} & \multicolumn{2}{|c|}{------Greenhouse area----- } & \multirow{2}{*}{$\begin{array}{l}\text { Number of farmers } \\
\text { registered on FRS }\end{array}$} & \multirow{2}{*}{$\begin{array}{l}\text { Number of insured farmers } \\
\text { affected by disasters }\end{array}$} \\
\hline & & hectare & $\%$ & & \\
\hline Aksu & 20.350 & 3.186 & 11.1 & 3.438 & 625 \\
\hline Serik & 43.500 & 4.250 & 14.8 & 3.793 & 1.651 \\
\hline Kumluca & 17.000 & 3.823 & 13.4 & 2.908 & 513 \\
\hline Subtotal (A) & 80.850 & 11.259 & 39.3 & 10.139 & 2.789 \\
\hline Other districts (B) & 279.395 & 17.393 & 60.7 & 29.394 & 954 \\
\hline Total $(\mathrm{A}+\mathrm{B})$ & 360.245 & 28.652 & 100.0 & 39.533 & 3.743 \\
\hline
\end{tabular}

Source: ANONYMOUS, 2019a and ANONYMOUS, 2019b.

value below 5 should not exceed $20 \%$ of the total cell number (KESKIN \&KOCABAS 1998).

Furthermore, the inclinations, views and opinions of farmers with and without agricultural insurance concerning agricultural insurance were evaluated using a five-point Likert scale. Today, one of the most widely used scale types in many areas of social sciences is the likert scale, and it was introduced to science by Rensis Likert in 1932. Considering the answers given by individuals to the questions asked in this scale, the scores of the reactions of each individual included in the sample are calculated (MALHOTRA, 2013). In this scale, the scores of the answers given by the individuals to the questions asked to the people can be calculated and the knowledge, attitude and behavior scores of the individuals about this subject can be calculated (KIRCAALI IFTAR, 1999). Likert scale is preferred by many researchers because it is easier and more economical than other scales. In Likert-type scales, generally equal numbers of positive and negative statements are included, and the respondents are scored whether they agree with these views or not (TEZBASARAN, 1996; BARDAKCI, 2013).

\section{RESULTS AND DISCUSSION}

\section{Socioeconomic characteristics}

Age is an important factor affecting attitude and behaviour of farmers toward agricultural production activities. The mean age of the interviewed farmers is 50.8. Their mean family size is 4 persons, mean farming experience is 27.5 years, mean greenhouse farming experience is 23.6 years and mean land size owned is 2.33 hectares. Table 2 shows the socioeconomic characteristics of the farmers and their businesses. Accordingly, the mean age of the insured farmers and uninsured farmers is 49.5 and 52.2, respectively. According to population projections of Turkey's elderly population ratio will rise to $10.2 \%$ in 2023 and will be among the very elderly population estimated. While the average age in Turkey is 32, the average age of people living in rural areas is 55. In the research area, the average age was found to be 50.8. Migration from rural to urban has increased rapidly due to reasons such as economic crises and the agricultural sector not bringing as much income as before, and the number of people engaged in farming in rural areas has decreased day by day. Especially the young people not embracing farming as a profession, the attractive power of the city caused them to prefer to live and work in cities instead of staying in the countryside. Thus, the elderly population remained in rural areas. Farming and greenhouse farming experience of uninsured farmers is higher than that of insured farmers. However, the total land and greenhouse assets of insured farmers are higher than those of uninsured farmers. The mean family size in Turkey is 3.4 . The mean household size in Antalya is 3.1 persons (TURKSTAT, 2018). The mean family size in the research location was found to be 4.0 persons (Table 2). $93.5 \%$ of the respondents are married, $3.5 \%$ single and $3 \%$ divorced or widow/ widower.

Educational attainment is an important characteristic in that it shows the socioeconomic level of rural communities. However, research indicates that the rate of literacy in the agricultural sector is lower than in other sectors (OZCATALBAS \& GURGEN, 1998). In the research location, $45 \%$ of the farmers have elementary school diploma, $21 \%$ high school diploma and $17.5 \%$ associate/

Ciência Rural, v.52, n.4, 2022. 
Table 2 - Socioeconomic characteristics of the farms under study.

\begin{tabular}{|c|c|c|c|c|c|c|c|c|}
\hline \multirow[t]{2}{*}{ General details } & \multicolumn{4}{|c|}{-------------------------Insured----------------------- } & \multicolumn{4}{|c|}{--------------------------Uninsured---------------------- } \\
\hline & Min & Max & Mean & Standard Deviation & Min & Max & Mean & Standard Deviation \\
\hline Farmer age (years) & 28 & 68 & 49.5 & 10.5 & 30 & 72 & 52.2 & 9.5 \\
\hline Family size (persons) & 3 & 6 & 4.4 & 1.1 & 2 & 6 & 3.6 & 1.4 \\
\hline Number of children (persons) & 1 & 3 & 1.95 & 0.7 & - & 4 & 1.3 & 1.1 \\
\hline Farming experience (years) & 5 & 50 & 25.8 & 11.1 & 10 & 55 & 29.3 & 12.1 \\
\hline Greenhouse experience (years) & 5 & 45 & 22.8 & 9.6 & 10 & 50 & 24.5 & 9.8 \\
\hline Total land size (hectare) & 0.3 & 1.5 & 2.79 & 2.7 & 0.1 & 11.0 & 1.87 & 2.42 \\
\hline Total greenhouse size (hectare) & 0.3 & 2.5 & 1.00 & 0.6 & 0.1 & 1.7 & 0.5 & 0.4 \\
\hline Cattle (head) & 2 & 15 & 7.4 & 4.7 & 1 & 12 & 5.4 & 3.7 \\
\hline Sheep and goats (head) & 10 & 30 & 16.7 & 10.0 & 4 & 13 & 8.7 & 4.8 \\
\hline Poultry (head) & 5 & 25 & 14.3 & 7.1 & 5 & 30 & 13.6 & 5.3 \\
\hline
\end{tabular}

bachelor's degree. In Turkey, the rate of illiteracy in the population aged 15 and over is $3.6 \%$. This rate is $1.1 \%$ for men and $6.1 \%$ for women (TUIK, 2018). The chi-square showed that there was a relationship between insured and uninsured farmers in terms of educational attainment (Table 3). Accordingly, it can be said that the educational attainment of the insured farmers is higher than that of uninsured farmers. In a study evaluating the perspective of apricot producers on agricultural insurance in Malatya province, the average age of the producers was 56.27 years, the education level was 4.01 years and the farming experience was 32.13 years (CUKUR et al.,2008). In other studies on agricultural insurance, it has been determined that the characteristics of the producers are similar to each other (YAVUZ, 2010; YILMAZ et.al., 2017; BAYRAMOGLU et.al., 2013; SAYIN et.al., 2014). The data obtained show that producers participate in agricultural production from an early age, so the education level is low. $71.5 \%$ of the farmers stated that they have borrowed agricultural loans in the last 5 years. The result of the chi-square test indicates that there is a relationship between insured and uninsured farmers in terms of borrowing loans. It can be said that insured farmers borrow more loans than uninsured farmers (Table 3). In a similar study which found that the rate of the farmer agricultural credit used (86.96\%) in the insured farm and is higher compared to non-insured farm $(59.52 \%)$ (YILMAZ et.al., 2014).

Table 3 - Education level of the farmers and borrowing by farms under study.

\begin{tabular}{|c|c|c|c|c|c|c|c|}
\hline & & \multicolumn{2}{|c|}{----------------Insured------------ } & \multicolumn{2}{|c|}{-----------Uninsured----------- } & \multicolumn{2}{|c|}{ 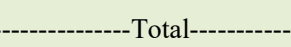 } \\
\hline & & Persons & $\%$ & Persons & $\%$ & Persons & $\%$ \\
\hline \multicolumn{8}{|c|}{ 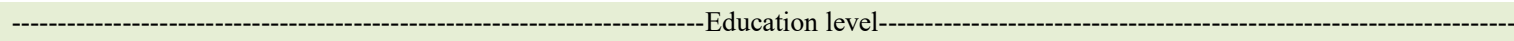 } \\
\hline Elementary school & & 37 & 37.0 & 53 & 53.0 & 90 & 45.0 \\
\hline Secondary school & & 18 & 18.0 & 15 & 15.0 & 33 & 16.5 \\
\hline High school & & 29 & 29.0 & 13 & 13.0 & 42 & 21.0 \\
\hline College/University & & 16 & 16.0 & 19 & 19.0 & 35 & 17.5 \\
\hline \multirow[t]{2}{*}{ Total } & & 100 & 100.0 & 100 & 100.0 & 200 & 100.0 \\
\hline & $\mathrm{SD}=3$ & $\chi^{2}=9.470$ & $>\quad \chi_{0.95}^{2}=7.815$ & \multicolumn{3}{|c|}{ Result: There exists a relationship } & \\
\hline \multicolumn{8}{|c|}{ 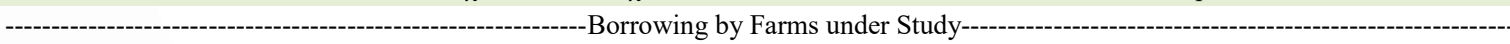 } \\
\hline Yes & & 84 & 84.0 & 59 & 59.0 & 143 & 71.5 \\
\hline No & & 16 & 16.0 & 41 & 41.0 & 57 & 28.5 \\
\hline \multirow[t]{2}{*}{ Total } & & 100 & 100.0 & 100 & 100.0 & 200 & 100.0 \\
\hline & $\mathrm{SD}=1$ & $\chi^{2}=14.133$ & $>\quad \chi_{0.95}^{2}=3.841$ & \multicolumn{3}{|c|}{ Result: There exists a relationship } & \\
\hline
\end{tabular}

Ciência Rural, v.52, n.4, 2022. 


\section{Opinions of farmers about agricultural insurance}

The interviewed farmers' level of knowledge about agricultural insurance is given in table 4. Insured farmers strongly agree with the statements "Agricultural insurance is a measure that farmers take to not be affected by natural disasters" and "Agricultural insurance is compensation by insurance companies for damages arising from natural disasters. Uninsured farmers strongly agree with the statement "Agricultural insurance is a kind of additional cost for farmers".

Loss of crops in greenhouses and damage to the greenhouse framework, covering material and technical equipment in the greenhouse arising from hail, storm, whirlwind, fire, landslide, earthquake, vehicle crash, snow and hail weight, and flood are covered within the framework of General Conditions and Tariffs and Instructions (TARSIM, 2019). The insurance coverage of all insured farmers interviewed in the study was found to include "covering, crop and framework". The interviewed farmers have more than one greenhouse with different types of covering. $65 \%$ of the insured farmers take out agricultural insurance for their glass greenhouses in which they engage in single cultivation, whereas $9 \%$ engage in double cultivation and $26 \%$ engage in both single and double cultivation.

The reasons why the interviewed farmers take out agricultural insurance were evaluated by Likert scale. Accordingly, farmers strongly agree with the statements "insuring the crop" (4.62), "avoiding any potential loss" (4.62), "insuring the income" (4.59) and "presence of disaster risk" (4.55). However, they strongly disagree with "opportunity to purchase machinery through credit sale" (1.38).
It is followed by "attending agricultural insurance training" (2.14), "media's influence" (2.16) and "opportunity to get farmer card from Ziraat Bank" (2.26) (Table 5).

The insured farmers were asked their opinion on agricultural insurance practices. The insured farmers interviewed in the study agree with the statements "unnecessary bureaucratic procedures", "very high waiver rates", "very high premiums", "insufficient government support". They disagree with the statement "inappropriate time of issuing a policy" (Table 6).

The insured farmers' expectations from the government concerning the agricultural insurance practices were evaluated and the data obtained are given in table 7. The insured farmers' expectations from the government concerning agricultural insurance practices are quite high. Expectation statements that the insured farmers agree and strongly agree are "Land registration problems should be resolved" (4.95), "Government support should be maintained" (4.17), "Farmers should be trained on importance of agricultural insurance" (4.64). Their level of agreement with the expectation statement concerning lifting of damage waiver rates (3.87) is lower compared to other expectation statements (Table 7).

Expectations of the insured farmers from insurance companies concerning agricultural insurance practices were evaluated. Accordingly, the major expectations of the farmers from insurance companies include "Damage assessment should be made in a timely manner" (4.67), "Specialised insurance adjusters should be commissioned in case of damage" (4.64), "Farmers' statements should be

Table 4 - Interviewed farmers' level of knowledge about agricultural insurance.

\begin{tabular}{|c|c|c|c|c|}
\hline \multirow[t]{2}{*}{ Level of knowledge } & \multicolumn{2}{|c|}{-------------Insured---------- } & \multicolumn{2}{|c|}{--------Uninsured---------. } \\
\hline & Mean & $\begin{array}{l}\text { Standard } \\
\text { Deviation }\end{array}$ & Mean & $\begin{array}{l}\text { Standard } \\
\text { Deviation }\end{array}$ \\
\hline It is a guarantee for the crops. & 4.42 & 0.57 & 4.04 & 0.57 \\
\hline It is a guarantee for the farmers' income. & 4.28 & 0.58 & 3.67 & 1.09 \\
\hline It is the future of farmers. & 3.83 & 0.92 & 3.43 & 1.09 \\
\hline It is a measure that farmers take to not be affected by natural disasters. & 4.58 & 0.49 & 4.18 & 0.55 \\
\hline It is a kind of government support for farmers. & 3.97 & 0.84 & 3.49 & 1.11 \\
\hline $\begin{array}{l}\text { It is compensation by insurance companies for damages arising from natural } \\
\text { disasters. }\end{array}$ & 4.58 & 0.49 & 4.17 & 0.79 \\
\hline It is a kind of additional cost for farmers. & 4.56 & 0.65 & 4.70 & 0.46 \\
\hline
\end{tabular}

Scale: $1=$ Strongly disagree; $2=$ Disagree; $3=$ Neutral; $4=$ Agree; $5=$ Strongly agree . 
Table 5 - Reasons why the interviewed farmers take out agricultural insurance $(\mathrm{N}=100)$.

\begin{tabular}{|c|c|c|c|c|c|c|c|c|}
\hline \multirow[t]{2}{*}{ Reasons for taking out agricultural insurance } & \multirow[t]{2}{*}{ Mean } & \multirow[t]{2}{*}{ Standard deviation } & \multicolumn{6}{|c|}{ - } \\
\hline & & & 1 & 2 & 3 & 4 & 5 & Total \\
\hline Presence of disaster risk & 4.55 & 0.85723 & 0 & 8 & 0 & 21 & 71 & 100 \\
\hline Avoiding any potential loss & 4.62 & 0.48783 & 0 & 0 & 0 & 38 & 62 & 100 \\
\hline Opportunity to purchase machinery through credit sale & 1.38 & 0.70754 & 72 & 21 & 4 & 3 & 0 & 100 \\
\hline Opportunity to get farmer card from Ziraat Bank & 2.26 & 1.69741 & 61 & 5 & 0 & 15 & 19 & 100 \\
\hline Media (Radio, Television, Internet, Newspaper, Magazine) & 2.16 & 1.42645 & 55 & 10 & 2 & 30 & 3 & 100 \\
\hline Other farmers taking out insurance & 3.03 & 1.61092 & 29 & 14 & 8 & 23 & 26 & 100 \\
\hline Provision of government support & 4.17 & 0.95405 & 0 & 7 & 17 & 28 & 48 & 100 \\
\hline Seeing that insured farmers are not affected by disasters & 3.60 & 1.34089 & 15 & 7 & 6 & 47 & 25 & 100 \\
\hline Insuring the crop & 4.62 & 0.48783 & 0 & 0 & 0 & 38 & 62 & 100 \\
\hline Insuring the income & 4.59 & 0.49431 & 0 & 0 & 0 & 41 & 59 & 100 \\
\hline Improving agricultural production & 4.15 & 1.13150 & 1 & 15 & 6 & 24 & 54 & 100 \\
\hline Attending agricultural insurance training & 2.14 & 1.33348 & 53 & 8 & 12 & 26 & 1 & 100 \\
\hline
\end{tabular}

Scale: $1=$ Strongly disagree; $2=$ Disagree; $3=$ Neutral; $4=$ Agree; $5=$ Strongly agree .

taken into account" (4.64), and "Damage assessment should be made impartially" (4.60) (Table 8).

The risks that the insured farmers interviewed in the study would like to see incorporated into the insurance coverage are given in table 9. The major risks that the insured farmers agree should be incorporated into the insurance coverage are drought and theft. The farmers are neutral (neither agree nor disagree) about the incorporation of damage by wild animals (2.69), low yield and quality of crops (3.31), and disease (3.39) risks into the insurance coverage.

The circumstances under which the insured farmers interviewed in the study may opt out of agricultural insurance are given in table 10. Accordingly, the farmers that agree with the statement "I would never opt out of agricultural

Table 6 - Opinions of insured farmers on agricultural insurance practices $(\mathrm{N}=100)$.

\begin{tabular}{|c|c|c|c|c|c|c|c|c|}
\hline \multirow[t]{2}{*}{ Views and opinions } & \multirow[t]{2}{*}{ Mean } & \multirow[t]{2}{*}{ Standard deviation } & \multicolumn{6}{|c|}{--------------------------0/0--------------------- } \\
\hline & & & 1 & 2 & 3 & 4 & 5 & Total \\
\hline Insufficient coverage of insurance & 3.19 & 1.40486 & 16 & 14 & 33 & 9 & 28 & 100 \\
\hline Unrealistic calculation of damage costs & 3.30 & 1.67874 & 20 & 24 & 7 & 4 & 45 & 100 \\
\hline $\begin{array}{l}\text { Failure of insurance companies to pay damage claims in a } \\
\text { timely manner }\end{array}$ & 2.58 & 1.46460 & 32 & 21 & 23 & 5 & 19 & 100 \\
\hline $\begin{array}{l}\text { Failure of insurance companies to make damage assessment } \\
\text { properly and in a timely manner }\end{array}$ & 2.54 & 1.69026 & 48 & 10 & 3 & 18 & 21 & 100 \\
\hline Failure of insurance adjusters to come in a timely manner & 2.58 & 1.51211 & 33 & 24 & 15 & 8 & 20 & 100 \\
\hline Very high insurance premiums & 3.80 & 1.50420 & 11 & 14 & 16 & 2 & 57 & 100 \\
\hline $\begin{array}{l}\text { Too many conditions outside the coverage } \\
\text { of insurance }\end{array}$ & 3.24 & 1.34930 & 17 & 11 & 22 & 31 & 19 & 100 \\
\hline Farmers' statements not taken into account & 3.02 & 1.56334 & 32 & 1 & 23 & 21 & 23 & 100 \\
\hline Very high waiver rates & 3.88 & 1.21672 & 5 & 9 & 23 & 19 & 44 & 100 \\
\hline Inappropriate time of issuing a policy & 2.25 & 1.29002 & 44 & 12 & 23 & 17 & 4 & 100 \\
\hline Insufficient government support & 3.52 & 1.43182 & 18 & 2 & 23 & 24 & 33 & 100 \\
\hline Unnecessary bureaucratic procedures & 3.94 & 1.17051 & 0 & 17 & 30 & 15 & 48 & 100 \\
\hline
\end{tabular}

Scale: $\quad 1=$ Strongly disagree; $2=$ Disagree; $3=$ Neutral; $4=$ Agree; $5=$ Strongly agree . 
Table 7 - Expectations of insured farmers from the government concerning agricultural. Insurance Practices $(\mathrm{N}=100)$.

\begin{tabular}{|c|c|c|c|c|c|c|c|c|}
\hline \multirow[t]{2}{*}{ Expectations from the government } & \multirow[t]{2}{*}{ Mean } & \multirow[t]{2}{*}{ Standard deviation } & \multicolumn{6}{|c|}{ 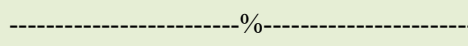 } \\
\hline & & & 1 & 2 & 3 & 4 & 5 & Total \\
\hline Coverage of insurance should be expanded. & 4.50 & 0.77198 & 0 & 0 & 17 & 16 & 67 & 100 \\
\hline $\begin{array}{l}\text { Requirement to register with the Greenhouse Registration } \\
\text { System should be lifted. }\end{array}$ & 4.18 & 1.07666 & 3 & 8 & 8 & 30 & 51 & 100 \\
\hline Government support should be increased. & 4.32 & 0.85138 & 0 & 6 & 7 & 36 & 51 & 100 \\
\hline Government support should be maintained. & 4.71 & 0.57375 & 0 & 1 & 3 & 20 & 76 & 100 \\
\hline Bureaucratic procedures should be streamlined. & 4.59 & 0.51434 & 0 & 0 & 1 & 39 & 60 & 100 \\
\hline Damage waiver rates should be lifted. & 3.87 & 1.24442 & 8 & 7 & 15 & 30 & 40 & 100 \\
\hline Insurance companies should be audited. & 4.53 & 0.65836 & 0 & 0 & 9 & 29 & 62 & 100 \\
\hline Insurance adjusters should be audited. & 4.64 & 0.64385 & 0 & 0 & 9 & 18 & 73 & 100 \\
\hline $\begin{array}{l}\text { Land registration, treasury land and shared land problems } \\
\text { should be resolved. }\end{array}$ & 4.95 & 0.21904 & 0 & 0 & 0 & 5 & 95 & 100 \\
\hline Insurance costs should be reduced. & 4.24 & 0.74019 & 0 & 0 & 18 & 40 & 42 & 100 \\
\hline $\begin{array}{l}\text { Farmers should be trained on importance of agricultural } \\
\text { insurance. }\end{array}$ & 4.64 & 0.48242 & 0 & 0 & 0 & 36 & 64 & 100 \\
\hline $\begin{array}{l}\text { Informative meetings concerning the novelties about } \\
\text { agricultural insurance should be held with farmers. }\end{array}$ & 4.49 & 0.71767 & 0 & 0 & 13 & 25 & 62 & 100 \\
\hline
\end{tabular}

Scale: $\quad$ 1=Strongly disagree; $2=$ Disagree; $3=$ Neutral; 4=Agree; $5=$ Strongly agree.

insurance" (4.07). They also agree with the statement "I would opt out of agricultural insurance if I lost my confidence in insurance companies" (3.71). They are neutral about the statements "I would opt out of agricultural insurance if government support discontinued" (2.65), "I would opt out of agricultural insurance if insurance cost rose too much" (2.90), "I would opt out of agricultural insurance if my income decreased" (3.14).

$39 \%$ of the uninsured farmers interviewed in the study state that they may take out agricultural insurance in the future, whereas $61 \%$ state that they will not. $46 \%$ of the uninsured farmers state that they may take out agricultural insurance if $50 \%$ of the

Table 8 - Expectations of insured farmers from insurance companies concerning agricultural. Insurance Practices $(\mathrm{N}=100)$.

\begin{tabular}{|c|c|c|c|c|c|c|c|c|}
\hline \multirow[t]{2}{*}{ Expectations from insurance companies } & \multirow[t]{2}{*}{ Mean } & \multirow[t]{2}{*}{ Standard deviation } & \multicolumn{6}{|c|}{ 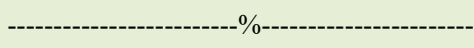 } \\
\hline & & & 1 & 2 & 3 & 4 & 5 & Total \\
\hline Insurance coverage should be described in detail. & 4.48 & 0.70324 & 0 & 0 & 12 & 28 & 60 & 100 \\
\hline $\begin{array}{l}\text { Specialised insurance adjusters should be commissioned } \\
\text { in case of damage. }\end{array}$ & 4.64 & 0.48242 & 0 & 0 & 0 & 36 & 64 & 100 \\
\hline Damage assessment should be made impartially. & 4.60 & 0.49237 & 0 & 0 & 0 & 40 & 60 & 100 \\
\hline Damage assessment should be made in a timely manner. & 4.67 & 0.47258 & 0 & 0 & 0 & 33 & 67 & 100 \\
\hline Coverage of insurance should be expanded. & 4.49 & 0.64346 & 0 & 0 & 8 & 35 & 57 & 100 \\
\hline Quantity of crops should be indicated correctly. & 4.57 & 0.65528 & 0 & 0 & 9 & 25 & 66 & 100 \\
\hline Publicity and information should be provided. & 4.39 & 0.73711 & 0 & 5 & 0 & 46 & 49 & 100 \\
\hline Farmers' statements should be taken into account. & 4.64 & 0.48242 & 0 & 0 & 0 & 36 & 64 & 100 \\
\hline Damage waiver rate should be lifted. & 4.16 & 1.16098 & 8 & 0 & 12 & 28 & 52 & 100 \\
\hline
\end{tabular}

Scale: $1=$ Strongly disagree; $2=$ Disagree; $3=$ Neutral; $4=$ Agree; $5=$ Strongly agree . 
Table 9 - Risks that insured farmers would like to see incorporated into insurance Coverage $(\mathrm{N}=100)$.

\begin{tabular}{|c|c|c|c|c|c|c|c|c|}
\hline \multirow[t]{2}{*}{ Risks } & \multirow[t]{2}{*}{ Mean } & \multirow[t]{2}{*}{ Standard deviation } & \multicolumn{6}{|c|}{ 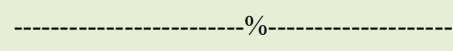 } \\
\hline & & & 1 & 2 & 3 & 4 & 5 & Total \\
\hline Theft & 3.51 & 1.59225 & 20 & 9 & 15 & 12 & 44 & 100 \\
\hline Low yield and quality of crops & 3.31 & 1.63111 & 27 & 8 & 4 & 29 & 32 & 100 \\
\hline Drought & 3.51 & 1.48048 & 18 & 5 & 22 & 18 & 37 & 100 \\
\hline Disease & 3.39 & 1.72267 & 32 & 0 & 4 & 25 & 39 & 100 \\
\hline Damage by wild animals & 2.69 & 1.64344 & 40 & 15 & 0 & 26 & 19 & 100 \\
\hline
\end{tabular}

Scale: $\quad 1=$ Strongly disagree; $2=$ Disagree; $3=$ Neutral; $4=$ Agree; $5=$ Strongly agree .

insurance premiums are paid by the government. $73 \%$ of the uninsured farmers are not aware of the fact that the government pays $50 \%$ of the insurance premiums (Table 11).

As to the reasons why the farmers interviewed in the study do not take out agricultural insurance, they agree with the statements "Lands are unregistered and shared" (4.25), "Lands are too fragmented" (3.54), "I do not have the habit of taking out agricultural insurance" (3.50). They disagree with the statements "I believe the cost of damage will not be paid" (2.52), "I believe the cost of damage will not be calculated correctly" (2.55), "I believe the cost of damage will not be paid in a timely manner" (2.56), "Negative feelings for the insurance companies" (2.56), and "My land is not in a region where there is a high risk of natural disasters" (2.58) (Table 12). In a similar study results show that the most important problems of farmers in government supported crop insurance were not registered with the farmer registration system, Fruit trees not covering been of the flowering period does not covered by insurance, disputes in evaluation on damage detection used by experts, too much bureaucratic procedures, high insurance premium, lack of knowledge about government supported crop insurance and lack of trust to insurance company (YILMAZ, 2014). In a study conducted in Antalya province, $53.2 \%$ of the producers stated the insufficiency of their income and the high insurance premiums as the reason for not having agricultural insurance, $36.1 \%$ did not need to take out insurance because of the low risk of natural disasters, and $10.6 \%$ indicated that the insurance did not fully cover the damage (SAYIN, et.al, 2014). In another study, it was determined that $93.10 \%$ of the producers did not have agricultural insurance due to the fact that they brought additional costs to their budgets, $6.90 \%$ did not have sufficient knowledge about insurance and they were insecure about insurance companies in the past (CUKUR et.al, 2008). According to the data obtained, the necessity of ensuring the confidence of producers in the agricultural insurance system arises. For this, it would be appropriate for public institutions and

Table 10 - Circumstances under which insured farmers may opt out of agricultural insurance $(\mathrm{N}=100)$.

\begin{tabular}{|c|c|c|c|c|c|c|c|c|}
\hline \multirow[t]{2}{*}{ Circumstances } & \multirow[t]{2}{*}{ Mean } & \multirow[t]{2}{*}{ Standard deviation } & \multicolumn{6}{|c|}{ 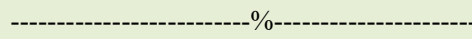 } \\
\hline & & & 1 & 2 & 3 & 4 & 5 & Total \\
\hline If insurance cost rose too much & 2.90 & 1.41064 & 16 & 36 & 10 & 18 & 20 & 100 \\
\hline If my income decreased & 3.14 & 1.42148 & 16 & 22 & 18 & 20 & 24 & 100 \\
\hline If I lost my confidence in insurance companies & 3.71 & 1.13969 & 8 & 5 & 20 & 42 & 25 & 100 \\
\hline If government support discontinued & 2.65 & 1.18386 & 16 & 38 & 18 & 21 & 7 & 100 \\
\hline I would never opt out & 4.07 & 1.05653 & 1 & 14 & 4 & 39 & 42 & 100 \\
\hline
\end{tabular}

Scale: $1=$ Strongly disagree; $2=$ Disagree; $3=$ Neutral; $4=$ Agree; $5=$ Strongly agree . 
Table 11 - Opinions of uninsured farmers

\begin{tabular}{|c|c|c|c|c|c|c|}
\hline \multirow[t]{2}{*}{ Opinions of uninsured farmers } & \multicolumn{2}{|c|}{-------Y Yes------ } & \multicolumn{2}{|c|}{--------No------- } & \multicolumn{2}{|c|}{--------Total------- } \\
\hline & $\mathrm{N}$ & $\%$ & $\mathrm{~N}$ & $\%$ & $\mathrm{~N}$ & $\%$ \\
\hline Consider taking out agricultural insurance in the future & 39 & 39.0 & 61 & 61.0 & 100 & 100.0 \\
\hline $\begin{array}{l}\text { Take out agricultural insurance if the government pays } 50 \% \text { of the insurance } \\
\text { premiums }\end{array}$ & 46 & 46.0 & 54 & 54.0 & 100 & 100.0 \\
\hline Aware of the fact that the government pays $50 \%$ of the insurance premiums & 27 & 27.0 & 73 & 73.0 & 100 & 100.0 \\
\hline
\end{tabular}

organizations, insurance companies and agricultural cooperatives to carry out training and publication studies on the importance of agricultural insurance. According to the findings of the research, it was determined that the education level of the farmers, their agricultural experience, agricultural income, the amount of land and their partnership status with agricultural organizations had a positive effect on the status of having agricultural insurance, while their dealing with non-agricultural activities had a

Table 12 - Reasons why the interviewed farmers do not take out agricultural insurance. $(\mathrm{N}=100)$.

\begin{tabular}{|c|c|c|c|c|c|c|c|c|}
\hline \multirow[t]{2}{*}{ Reasons for not taking agricultural insurance } & \multirow[t]{2}{*}{ Mean } & \multirow[t]{2}{*}{ Standard deviation } & \multicolumn{6}{|c|}{ 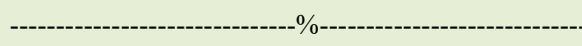 } \\
\hline & & & 1 & 2 & 3 & 4 & 5 & Total \\
\hline $\begin{array}{l}\text { I do not have the habit of taking out agricultural } \\
\text { insurance. }\end{array}$ & 3.50 & 1.32192 & 10 & 20 & 4 & 42 & 24 & 100 \\
\hline $\begin{array}{l}\text { I do not have sufficient information about } \\
\text { agricultural insurance. }\end{array}$ & 3.13 & 1.36074 & 17 & 22 & 5 & 43 & 13 & 100 \\
\hline $\begin{array}{l}\text { I do not have the financial means to take out } \\
\text { agricultural insurance. }\end{array}$ & 3.21 & 1.51954 & 21 & 19 & 2 & 34 & 24 & 100 \\
\hline Insurance premiums are very high. & 3.12 & 1.38739 & 13 & 30 & 10 & 26 & 21 & 100 \\
\hline $\begin{array}{l}\text { I believe that agricultural insurance is an } \\
\text { unnecessary cost. }\end{array}$ & 3.37 & 1.40457 & 10 & 29 & 2 & 32 & 27 & 100 \\
\hline Negative rumours about insurance companies & 2.56 & 1.44474 & 25 & 42 & 3 & 12 & 18 & 100 \\
\hline $\begin{array}{l}\text { I believe that damage assessment will not be } \\
\text { made correctly. }\end{array}$ & 2.59 & 1.08334 & 11 & 48 & 18 & 17 & 6 & 100 \\
\hline $\begin{array}{l}\text { I believe that the cost of damages will not be } \\
\text { calculated correctly. }\end{array}$ & 2.55 & 1.19236 & 15 & 48 & 14 & 13 & 10 & 100 \\
\hline $\begin{array}{l}\text { I believe that the cost of damages will not be } \\
\text { paid. }\end{array}$ & 2.52 & 1.14133 & 15 & 48 & 14 & 16 & 7 & 100 \\
\hline $\begin{array}{l}\text { I believe that the cost of damages will not be } \\
\text { paid in a timely manner. }\end{array}$ & 2.56 & 1.19189 & 15 & 47 & 15 & 13 & 10 & 100 \\
\hline Damage waiver rate is high. & 2.80 & 1.23091 & 15 & 32 & 21 & 22 & 10 & 100 \\
\hline Insufficient coverage of insurance & 2.68 & 1.15365 & 15 & 36 & 21 & 22 & 6 & 100 \\
\hline $\begin{array}{l}\text { The procedures for taking out insurance are } \\
\text { burdensome and the terms of contract are harsh. }\end{array}$ & 3.03 & 1.31391 & 13 & 31 & 10 & 32 & 14 & 100 \\
\hline $\begin{array}{l}\text { I believe that the government will pay the cost of } \\
\text { damages in case of a huge disaster. }\end{array}$ & 3.38 & 1.20420 & 6 & 26 & 8 & 44 & 16 & 100 \\
\hline Belief in fate & 2.60 & 1.26331 & 27 & 23 & 16 & 31 & 3 & 100 \\
\hline Lands are too fragmented. & 3.54 & 1.29817 & 12 & 14 & 3 & 50 & 21 & 100 \\
\hline Land registration and share problems & 4.25 & 1.17529 & 4 & 11 & 2 & 22 & 61 & 100 \\
\hline $\begin{array}{l}\text { My land is not in a region where there is a high } \\
\text { risk of natural disasters. }\end{array}$ & 2.58 & 1.12079 & 8 & 62 & 0 & 24 & 6 & 100 \\
\hline
\end{tabular}

Scale: $\quad 1=$ Strongly disagree; $2=$ Disagree; $3=$ Neutral; $4=$ Agree; $5=$ Strongly agree . 
negative effect. The most important problem of the farmers in the field of research is that those who have state land or share title cannot register in the farmer registration system. Therefore, farmers cannot apply for agricultural insurance. In addition, it was determined that the farmers did not have the habit of having insurance, the insurance premiums were high and they could not have it because they did not have sufficient income. It was effective for those who had insurance to see that their losses were compensated in case of a natural disaster in their vicinity. As much as the vast majority of farmers take out insurance from cooperatives or banks to benefit from reduced credit and government support. These data obtained; YAVUZ (2010), TAN et al. (2011), TUMER (2011), PEZIKOGLU et al. (2012), ASLAN et al. (2012), YILMAZ (2014), KARAMURSEL et al. (2014), SAYIN et al. (2014), TASCI et al. (2014), AYDIN et al. (2016), YILMAZ et al. (2017) and TUFAN et al. (2019), similar to the findings of the studies conducted. In short, though in different regions, farmers' opinions and problems about the agricultural insurance system are similar. In order to solve these problems, the relevant ministry needs to produce new agricultural policies.

\section{CONCLUSION}

In recent years, significant increases have been observed in the number and severity of natural disasters due to global warming and greenhouse gas effects. In short, even in countries using the most advanced technologies, agricultural production is still under the influence of natural conditions that are not under the control of the farmer. This situation negatively affects both the income of the farmer and the country's economy. Today, agricultural insurance systems come to the fore as one of the most important risk management elements that unite farmers, government and insurance companies in order to cope with these destructive forces of nature.

Agricultural insurance systems applied in the world vary depending on the development level of the countries, their agricultural structure, climate characteristics, socio-economic structure and the agricultural policies they implement. It has been observed that state-supported agricultural insurance systems are generally successful. As a matter of fact, in the USA, where agricultural insurance is the most developed, the ratio of state support to total premium is $72 \%$ and $80 \%$ of the insurable areas are insured.

Agricultural insurance is a system that guarantees the farmer against the damages of natural disasters that may occur during the agricultural production period. Although agricultural insurance is of course not a solution to all the problems of the agricultural sector and the rural areas, it has an important role in the healthy development of the sector. The aim of the farmers who have agricultural insurance is to eliminate the fluctuations and damages that may occur in income by insuring their livelihood agricultural products against various risks. Sustainable agriculture and rural development can be mentioned as the number of people who have agricultural insurance is high.

In this study, the socioeconomic status of insured and uninsured farmers who grow vegetables in greenhouses in Aksu, Serik and Kumluca districts of Antalya, the opinions of insured farmers about agricultural insurance practices, the reasons why uninsured farmers do not take out agricultural insurance and their expectations were identified.

The major reasons why farmers do not take out agricultural insurance are that the lands are unregistered, shared, too fragmented, and that they do not have the habit of taking out agricultural insurance. The farmers disagree with reason statements "I believe that the cost of damages will not be paid", "I believe that the cost of damages will not be calculated correctly", "I believe that the cost of damages will not be paid in a timely manner", "Negative rumours about insurance companies", "My land is not in a region where there is a high risk of natural disasters". It was found that the uninsured farmers were unsettled about taking out agricultural insurance in the future production periods. However, they state that they would take out insurance if the procedures were streamlined, the government support increased, their income increased or the cost of insurance decreased.

Expectations of the insured farmers from the government concerning agricultural insurance practices are resolution of land registration problems, maintenance of government support, training of farmers on importance of agricultural insurance, auditing of insurance adjusters and lifting of damage waiver rates. Expectations of the farmers from insurance companies include timely assessment of damage, paying attention to farmers' statements, commissioning of specialised insurance adjusters in case of damage, and impartial damage assessment. While the percentage of farmers stating that they would never opt out of agricultural insurance, the percentage of farmers stating that they would opt out of agricultural insurance if they lost their confidence in insurance companies is also high. It was found that insured farmers would be neutral about opting 
out of insurance if they lost their confidence in the insurance companies, the state support discontinued, their insurance premiums rose too much and their income decreased.

According to the similar research results, it is seen that the farmers both do not have information about the agricultural insurance system and do not trust the system. Especially, in order to break the judgment that experts are not found in the correct damage determination, it is necessary to urgently create proficient expert staff in a certain product group. For this, it would be appropriate for the experts employed to undergo a second training by specialized institutions (research institutes or universities affiliated with the Ministry of Agriculture and Forestry) regarding herbal products grown in the working areas after completing their basic training. In addition, it is important that farmers are informed that they have the right to appeal if they find the assessments made by the experts incorrect / incomplete. Informing farmers about the right to appeal can be done by private insurance companies at the stages of policy preparation and claim reporting. Farmers' belief that agricultural insurance protects them, is fair and reliable, is a prerequisite for the insurance system to be successful. The fact that the farmers express that the experts do not make objective assessments and their doubts about the independence of the experts jeopardize the reliability of the system. For this reason, it is very important to inform the farmers about the position of the experts and their assignment processes by TARSIM and to eliminate this wrong perception. Including the subject of communication techniques in the basic training program for experts will strengthen the relationship between the farmer and the expert. The high level of exemption rates and premium prices are the main problems of farmers related to insurance costs. Calculating the premium amount, premium support and exemption rates within the framework of state facilities, based on actuarial studies, in a way that will also address the expectations of the farmer will increase participation in the system and also ensure the sustainability of the system. In addition, continuing the state support for insurance premiums at least $50 \%(60 \%$ in drought insurance and $66.7 \%$ in frost coverage) and increasing state support, if state resources are appropriate, will positively affect the decisions to have agricultural insurance.

It is known that the Ministry of Agriculture and Forestry has carried out many projects, programs and training studies on the spread and adoption of innovations among farmers. However, according to the data obtained, it is seen that the ministry has not carried out a comprehensive extension study and has not determined a policy on the spread and adoption of agricultural insurance to date. In addition, the insufficient knowledge of agricultural insurance for those working as extension staff in insurance companies, public and private institutions prevents the attention given to this issue. Therefore, the desired point in the number of farmers who took out agricultural insurance could not be reached. According to the data obtained from the studies on the subject, it has been determined that the farmers do not have insurance because they do not have a habit of insurance, their income is low, they do not have sufficient savings and investment opportunities, and the fatalistic traditional structure is effective. In addition, it can be said that farmers do not have enough information about the agricultural insurance system and do not have insurance because they do not trust insurance companies.

There should be constant communication opportunities between farmers and insurance companies. Insurance companies should not deal with farmers solely for insurance reasons. In particular, there should be frequent exchanges of ideas with young farmers. Instead of generating solutions by taking into account the wishes of farmers on a local basis, instead of general problems related to the agricultural insurance system, TARSIM will increase participation in insurance. For example; In order for farmers to adopt agricultural insurances and raise awareness about its importance, more studies and awareness-raising activities should be carried out. In addition, agricultural insurance applications can be increased with the participation of the wives of male farmers in the awareness raising meetings and with the contribution of women farmers who avoid more risks than men. The diversification of the state support rates in premium prices according to regions and products may increase insurance production. Agricultural insurance is a branch that requires more technical, complex and expertise compared to other types of insurance. It is thought that raising agricultural insurers who can communicate well with the farmer, understand her production conditions, possibilities and expectations, and their participation in the insurance sector will contribute to the development of the sector.

In conclusion, favourable developments have occurred regarding the agricultural insurance practices in Turkey and the number of farmers taking out agricultural insurance has risen over the years. Nevertheless, there are still problems with agricultural insurance practices. The major one 
is that the procedures for taking out agricultural insurance are burdensome and complicated for uneducated farmers. Particularly, the farmers that do not own land and grow vegetables on rented land are required to submit their rental contracts and many other documents. Furthermore, farmers carrying out agricultural activities on their portion of inherited land or on treasury land cannot take out agricultural insurance. To overcome this issue, two different entries can be made into the system: "registered land" if the farmer has a title deed and "land with real estate record" if the farmer does not have a title deed. Thus, the impediment that prevents farmers from taking out agricultural insurance will be eliminated. Another concern is that farmers should be trained on risks of natural disasters by provincial/district directorates of agriculture and forestry. The training should underline the importance of agricultural insurance and focus on how farmers can make their existing greenhouses protected or what they should pay attention to when choosing the location of a new greenhouse.

\section{ACKNOWLEDGEMENTS}

This paper was supported by the Scientific Research Projects Administration Unit Akdeniz University.

\section{DECLARATION OF CONFLICT OF INTEREST}

The authors declare no conflict of interest. The founding sponsors had no role in the design of the study; in the collection, analyses, or interpretation of data; in the writing of the manuscript, and in the decision to publish the results.

\section{AUTHORS' CONTRIBUTIONS}

All authors critically revised the manuscript and approved of the final version.

\section{REFERENCES}

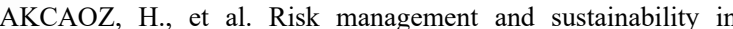
banana production: A case study from Turkey. Journal of Food Agriculture \& Environment, 7(2): '283-294, 2009. Available from: <https://www.wflpublisher.com/Abstract/1640>. Accessed: Jun. 16, 2020. doi: 10.1234/4.2009.1640.

AKCAOZ, H., et al. Risk and sustainability in tobacco production in Turkey|. Journal of Food Agriculture \& Environment, 8(3\&4):717-722, 2010. Available from: $<$ https://www.wflpublisher. com/Abstract/3324>. Accessed: Jul. 25, 2020

AKTER, S., et al. Determinants of participation in a catastrophe insurance programme; empirical evidence from a developing country, Australian Agricultural and Resource Economics Society 52 Annual Conference, 2008. Available from: $<\mathrm{https}$ ://ageconsearch.umn.edu/ record/5984>. Accessed: Jun. 26, 2020. doi: 10.22004/ag.econ.5984.
ANONYMOUS. Antalya provincial directorate of agriculture and forestry provincial and district briefing reports, Antalya, 2019a. Available from: <https://antalya.tarimorman.gov.tr/Menu/72/ Brifingler $>$. Accessed: May, 20, 2020

ANONYMOUS. Compiled from the records of antalya provincial directorate of agriculture and forestry, Antalya, 2019b. Available from: <https://antalya.tarimorman.gov.tr/Menu/60/Antalya $>$. Accessed: May, 20, 2020.

ASLAN, A., et al. The approach of farmers on crop production insurances applications in Malatya province. X. National Agricultural Economics Congress, Konya, Turkey, 5-7 September 2012, volume: 2, page: 1156-1160, 2012. Available from: <http:// tarekoder.org/tarim-ekonomisi-kongreleri>. Accessed: Feb. 15, 2020.

AYDIN, B., et al. Farmer approach to agricultural insurance applications in Kirklareli and Edirne provinces. Derim, Western Mediterranean Agricultural Research Institute, Antalya, 33(2): 249-262, 2016. Available from: <http://www.derim.com.tr/tr/pub/ issue/25454/267910>. Accessed: May, 20, 2020. doi: 10.16882/ derim.2016.267910.

BARDAKCI, S. Developing a classroom activity scale for primary school students, reliability and validity study: Sivas province application (Master of Science Thesis). Sivas Cumhuriyet University, Social Science Institute, 2013. Available from: $<$ https:// tez.yok.gov.tr/UlusalTezMerkezi/>. Accessed: Feb. 12, 2020.

BAYRAMOGLU, Z., et al. Risk sources and risk strategies in agricultural production: a case of Cumra. Selcuk Journal of Agricultural and Food Sciences, Konya, 27(1): 46-54, 2013. Available from: <http://sjafs.selcuk.edu.tr/sjafs/article/view/696>. Accessed: Apr. 25, 2020.

CABAS, J. H., et al. Modeling exit and entry of farmers in a crop insurance program, Agricultural and Resource Economics Review, 37(1): 92-105, 2008. Accessed: Feb. 12, 2020. doi: $10.1017 / \mathrm{S} 1068280500002173$.

CICEK, A.; ERKAN, O. Research and sampling methods in agricultural economics. Gaziosmanpasa University Faculty of Agriculture, Tokat, Publication Number: 12, Lecture Notes Series: 6, 1996.

CUKUR, F., et al. The evaluation of apricot farmers' behaviours toward agricultural insurance for risk transfer in malatya province: the case study of Dogansehir district, Polatdere village. Ege University Faculty of Agriculture Journal, İzmir, 45 (2): 103 111, 2008. Available from: <https://dergipark.org.tr/tr/download/ article-file/59285>. Accessed: Apr. 25, 2020

ENJOLRAS, G.; SENTIS, P. The main determinants of insurance purchase an empirical study on crop insurance policies in France. Paper prepared for presentation at the 12th EAAE Congress "people, food and environments: global trends and european strategies", Gent (Belgium), 26-29 August 2008. Available from: <https://ageconsearch.umn.edu/record/44395>. Accessed: Feb. 20 ,2021. doi: 10.22004/ag.econ.44395.

ERTAN, A.; GOK, M. Analysis of the effective factors of Egirdir agricultural producers' decision process on having an agricultural insurance. Ordu University Institute of Social Sciences Journal of Social Sciences Researches. 3(5): 66-76, 2012. Available from: $\quad<$ https://dergipark.org.tr/tr/download/article-file/273585>. Accessed: Feb. 12, 2020. 
FIELDS, D.; GILLESPIE, J. Beef producer preferences and purchase decisions for livestock price insurance. Journal of Agricultural and Applied Economics, 40(3):789-803, 2008. Accessed: May, 15, 2020. doi: 10.1017/S1074070800002339.

HAYRAN, S., et al. Factors affecting forage plant producers' decisions on making agricultural insurance: the case of Balikesir province. Agriculture Engineering, 369: 22-29, 2020. Accessed: May, 15, 2020. doi: 10.33724/zm.691105.

KARAMURSEL, D., et al. Approaches of farmers to plant crop insurance applications in Isparta. XI. National Agricultural Economics Congress, Samsun, Turkey. 3-5 September 2014, volume: 2, page:1051-1059, 2014. Available from: <http:// tarekoder.org/tarim-ekonomisi-kongreleri>. Accessed: Feb, 15, 2020 .

KESICI, T.; KOCABAS, Z. Biostatistics. Ankara University Faculty of Pharmacy. Publication Number: 79, 1998. Ankara, Turkey.

KIRCAALI IFTAR, G., Research methods in social sciences. Anadolu University Publication No: 1081, Distance Education Faculty Publication, No: 601, 13-22, 1999.

KIZILOGLU, R. Determining factors affecting farmers agricultural insurers a case study of Aksehir district of Konya province. Alinteri Journal of Agriculture Sciences, 32(1): 19-26, 2017. Available from: <https://dergipark.org.tr/tr/pub/alinterizbd/ issue/29988/293243>. Accessed: May, 15, 2020. doi: 10.28955/ alinterizbd. 293243

KUTLAR, I. Analysis of the sources of agricultural information available to greenhouse tomato growers in Turkey. Fresenius Environmental Bulletin. 28(9):6825-6835, 2019. Available from: $<$ https://www.prt-parlar.de/download_feb_2019/>. Accessed: Feb. $15,2020$.

MALHOTRA, A. K. Curbing creative accounting: roleand effectiveness of ethics. International Journal of Finance and Policy Analysis, 5(2), 15- 26, 2013. Available from: <http:// www.brownwalker.com/journal/1612337481>. Accessed: May, 20, 2020.

OZCATALBAS, O.; GURGEN, Y. Agricultural extension and communication. Baki Books and Publishing, ISBN: 975-7202402-3, 1998. Adana, Turkey.

OZKAN, B., et al. Economic analysis of farms produced greenhouse vegetable crops in Antalya province. Bahce, Journal of Yalova Horticultural Research Institute, Yalova, Turkey, 30(1-2):109-115, 2001. Available from: <https://dergipark.org.tr/ tr/pub/bahce/issue/3345/46281>. Accessed: Apr. 20, 2020.

PEZIKOGLU, F., et al. Approaches of farmers to the insurance applications for crop product in Bursa provinces. X. National Agricultural Economics Congress, 5-7 September 2012, Konya, Turkey, volume: 2, page:1098-1102, 2012. Available from: $<\mathrm{http}$ ://tarekoder.org/tarim-ekonomisi-kongreleri $>$. Accessed: Feb. 15,2020

SAYIN, B., et al. Farmers' point of view on agricultural insurance applications in Antalya province. XI. National Agricultural Economics Congress, Samsun, Turkey, 3-5 September 2014, volume: 2, page:1077-1084, 2014. Available from: $<$ http://tarekoder org/tarim-ekonomisi-kongreleri>. Accessed: Feb. 15, 2020.
TAN, S., et al. The examination of the demand and tendencies of producers on agricultural insurance: the case of Lapseki town of Canakkale province. X. National Agricultural Economics Congress, Konya, Turkey, 5-7 September 2012, volume:2, page:1207-1214, 2012. Available from: <http://tarekoder.org/ tarim-ekonomisi-kongreleri>. Accessed: Feb, 15, 2020.

TARSIM (2019). Agricultural insurance pool. Annual Reports. Available from: $<$ https://www.tarsim.gov.tr>. Accessed: May, 15, 2020.

TASCI, R., et al. Farmer's risk management and agricultural insurance practices in Ankara, Corum and Kayseri province. XI. National Agricultural Economics Congress, Samsun, Turkey, 3-5 September 2014, volume:2, page:1035-1041, 2014. Available from: $\quad<\mathrm{http}: / /$ tarekoder.org/tarim-ekonomisi-kongreleri> Accessed: Feb. 15, 2020.

TEZBASARAN, A. A. Likert type scale development guide. Ankara: Turkish Psychologists Association Publications, 1996.

TUFAN, A. H., et al. Agricultural insurance in turkey: agricultural insurance awareness of the producers in Aydın. Journal of Aydın Faculty of Economics, 4(1):44-60, 2019. Available from: <https:// dergipark.org.tr/tr/pub/aifd/issue/50011/524731>. Accessed: May, 10,2020

TUMER, E. İ. Determination of willing to buy crop insurance: the case of Tokat province. Journal of Agricultural Faculty of Ataturk University, Erzurum, Turkey. 42(2):153-157, 2011. Available from: <https://dergipark.org.tr/tr/pub/ataunizfd/ issue/3015/41859>. Accessed: Jun. 01, 2020

TURKSTAT. Statistics by theme, population and demography, address based population registration statistics, compiled from average household size data by provinces. Turkish Statistical Institute, Ankara, 2018. Available from: <http://www.tuik.gov.tr $>$. Accessed: Jun. 01, 2020.

TURKSTAT. Statistics by theme, agriculture, crop production statistics, compiled from greenhouse production data. Turkish Statistical Institute, Ankara. 2019. Available from: <http://www. tuik.gov.tr>. Accessed: Jun. 01, 2020.

YAMANE, T. Basic Sampling Methods (Translation from Taro Yamane: Esin, A., Aydın, C., Bakir, M.A., Gurbuzsel, E), Istanbul, Turkey, Literature Publishing: 53, 2001.

YAVUZ, G. G. Analyzing of effective factors on farmers' decision making process in agricultural insurance in Polatli district (Unpublished Doctoral Dissertation). Ankara University Institute of Science, Department of Agricultural Economics, 2010. Available from: <https://tez.yok.gov.tr/UlusalTezMerkezi/>. Accessed: Feb. 12, 2020.

YILMAZ, H., et al. An empirical analysis on the determinants of government-subsidised crop insurance purchase in grape production in Turkey. Erwerbs-Obstbau, 59:51-60, 2017. Available from: $<$ https://link.springer.com/article/10.1007/s10341-016-0297-3>. Accessed: Apr, 20, 2020. doi: 10.1007/s10341-016-0297-3.

YILMAZ, H. Analysis in terms of apple producers of government supported crop insurance policies as a risk management tool in Turkey. Acta Sci. Pol., Hortorum Cultus, 13(5):3-12, 2014 Available from: $<\mathrm{http}: / / \mathrm{www}$.hortorumcultus.actapol.net/ volume13/issue 5>. Accessed: Apr. 20, 2021. 